\title{
An Error Analysis of Tiyao (Abstract) of Students' Final Project Reports at Department of Mandarin Unsoed
}

\author{
Icha Fais N.K ${ }^{1}$, Henggar $\mathrm{P}^{2}$, Chendy A.P.S ${ }^{3}$ \\ \{ichafaisfangyuan@gmail.com ${ }^{1}$, henggarpr@gmail.com ${ }^{2}$, chen.sulistyo@gmail.com ${ }^{3}$ \} \\ Faculty of Humanities, Jenderal Soedirman University Purwokerto.
}

\begin{abstract}
Tiyao is a Mandarin summary on the final project report of Mandarin Department's students at Universitas Jenderal Soedirman, Purwokerto. This study analyzed the writing errors in tiyao. The researchers observed Mandarin Department graduated student's tiyao, then analyzed the errors, and distributed the questionnaire to get suggestion on making improvements to the teaching system, especially the translation. The main objective of this study was to determine the form of writing errors and to find out the factors that caused the writing errors in the project report of Mandarin Department students UNSOED. As well as to develop the tiyao writing method of the students final project report in Mandarin Department UNSOED. Data collection was done by observation techniques, and interviews. The results showed that the form of errors made by students was due to a lack of students' understanding in Mandarin vocabulary and due to a lack of understanding the correct Mandarin sentence structure.
\end{abstract}

Keywords: Tiyao, translation, Mandarin

\section{Introduction}

The increase in China's economic sector in recent years has influenced the flow of investment, tourism and cultural communication between China and many countries in the world including Indonesia. In Indonesia, the largest number of tourists is those tourists from China. The increase also occurred in investment cooperation, such as steam power plant projects, the car industry, and the cement industry. Femonema of the increasing number of Chinese tourists and investment from China is in line with an increase in the frequency of Mandarin usage in Indonesia. This is a great opportunity for Indonesia to produce Mandarinspeaking human resources with the aim of increasing effectiveness in communication in various fields of cooperation with China and increasing Indonesian people employment.

To achieve this great opportunity, Mandarin education is needed to be able to produce graduates who are competent in the field of mastering Mandarin. Nowadays, Mandarin has become one of subects that is offered by education institutions from the level of kindergartens to high schools, not even a few universities, both public and private, have opened Mandarin study programs, one of them is Jenderal Soedirman University Purwokerto.

Mandarin study program at Jenderal Soedirman University is an Associate Degree with two final majors namely tourism and Mandarin translation. The main competencies in learning Mandarin are speaking, reading, listening, and writing competencies. In addition to these four 
main competencies, students also deepen their translation skills, so that they are expected to be competent graduates in the field of translation and tourism. As Associate Degree program, one of the graduation requirements is to write a working project report as a final assignment.

The students' partical work project report consists of a summary or abstract, introduction, literature review, general review, discussion, and conclussion. The reports are written in Ind onesian, but in the abstract or in Mandarin is tiyao, students are required to write in Mandarin. Tiyao consists of background, objectives, benefits, methods, research results, and conclusions. The general summary consists of 200 to 300 words. The basic aim of tiyao is to make the reader understand the purpose of research. The student's practical work report encourages researchers to observe the suitability of sentence structure and content on the practical work report of students graduated from the diploma program of Jenderal Sudirman University. The results of research on tiyao (abstract) in the practical work report is expected to improve the Tiyao writing ability of the graduates of the Mandarin study program.

This study applies the theory of Corder (1967) about errors in language or known as Error Analysis (EA). According to Corder, errors are divided into two types, as follows: (1) errors caused by a lack of knowledge about language rules, by developing students' knowledge of the second language system, which is called "error", (2) errors that caused by factors of fatigue, tiredness, and lack of attention called performance factors. This performance error is a physical error that is often referred to as "mistake". The "mistake" can be corrected if the speaker / writer is reminded, while the "error" is a language deviation of students who learn languages at a certain level (in Jianqin, 2012: 78).

The reasearch problems in this study are what arethe forms of tiyao writing errors in students' practical work project reports of Associate Degree Mandarin departement UNSOED is; what factors caused the writing error in students' practical work project reports of Associate Degree Mandarin departement UNSOED are; and how the right writing process of tiyao in students' practical work project reports of Associate Degree Mandarin departement UNSOED is. In the process of learning the second language, in this case Mandarin, the source of student's error in making sentences in Mandarin is influenced by several factors, as Corder (1967) mentioned: 1) influence from the Mother tongue; 2) disorders originating from the second language, 3 ) influence from culture, and 4) influence from learning methods and ways of communication.This research is a study within the grammar scope of Mandarin writing based on the theory of Language Error Analysis described by Corder (1967), and using the Mandarin grammar xiandai ba bai ci as a standard grammar reference. In analyzing Mandarin grammar writing errors, this research is supported by Corder's Overt and Covert error analysis methods. Overt errors refer to grammatical errors, word selection and other errors that are clearly seen in a sentence. Covert error refers to a sentence that is correct grammatically, but in certain conditions the sentence does not fit the context.

\section{Method}

This study belongs to qualitative research. According to Sukardi (2003: 157), the qualitativemethod is a research in the form of collecting data to test the research problems or hypotheses related to current conditions and reporting the state of the object and subject under study according to the true and real condition. The technique of collecting data used are observation and interviews. The data was collected from the writing errors in Tiyao in the Final Project of the Mandarin study program students at UNSOED graduated in 2018. The 
interview technique was conducted with students and lecturers of Mandarin to find out the condition of the learning system as preparation for writing the Final Project. Descriptive methods conclude the results of the study through simple statistics. The main objective of this research is to make a systematic and accurate explanation of Tiyao's writing errors in the final assignment of the Associate Degree Mandarin study program students at UNSOED. In this study, researchers used modified data analysis techniques such as the experts revealed in Tarigan (1998: 62), following modification data analysis techniques in this study: (1) Classifying data, (2) Classifying errors, (3) Describing errors, (4) Correcting errors and (5) Finding the cause of the error.

\section{Results and Discussion}

Based on the reasearch's results conducted by researchers about Tiyao, the final assignment of Associate Degree of Mandarin students has found several grammatical errors in writing Mandarin sentences. In this case, the researcher breaks them into several categories of errors based on surface tactics according to Tarigan (1988: 145), including omission, addition, misformation, and misordering. But in one sentence, there are found several different forms of errors, so that at the end of the sentence the researcher gives a sign $\left(^{*}\right)$.

\subsection{Omission}

Omission errors are included in the grammatical order which is characterized by the absence of a grammatical item or morpheme that should be in the sentence. Errors of omission lead to confusion of meaning because omission of words that should not occur. The following are some examples of errors in disappearances that have been categorized by researchers in several types:

\subsubsection{Subject Omission}

Subjects or 主语（zhǔyǔ） in Mandarin according to (Li Delu, 2016: 24) are a sentence element that serves to explain the topic to be discussed. Subjects in Mandarin can be either people or events, so subjects in general are always placed at the beginning of the sentence. The following are some examples of errors in omitting the subject in a students' final projects:

Table 1. Subject Omission

\begin{tabular}{|c|c|c|}
\hline No & Subject Omission & Mandarin grammar standard \\
\hline 1 & 翻译转单的过程有三个阶段。(*) & 作者在翻译转单的过程中有三个阶段。 \\
\hline \multirow{4}{*}{2} & $\begin{array}{l}\text { Proses menerjemahan brosur memiliki } \\
\text { tiga tahapan. }\end{array}$ & $\begin{array}{l}\text { Penulis pada saat proses menerjemahkan brosur } \\
\text { memiliki tiga tahapan. }\end{array}$ \\
\hline & 收集文件的时候，作者用了四种方 & 作者在收集文件的时候用了四种方法是图书研 \\
\hline & 法是图书研究方法, 观察方法, 采 & 究方法, 观察方法, 采访方法, 汶览互联网。 \\
\hline & $\begin{array}{l}\text { 访方法, 汶览互联网。 } \\
\text { Pada saat pengumpulan data, penulis } \\
\text { menggunakan empat jenis metode, } \\
\text { yaitu metode studi pustaka, metode }\end{array}$ & $\begin{array}{l}\text { Penulis pada saat pengumpulan data, } \\
\text { menggunakan empat jenis metode, yaitu metode } \\
\text { studi pustaka, metode observasi, metode } \\
\text { wawancara, metode jelajah internet. }\end{array}$ \\
\hline
\end{tabular}




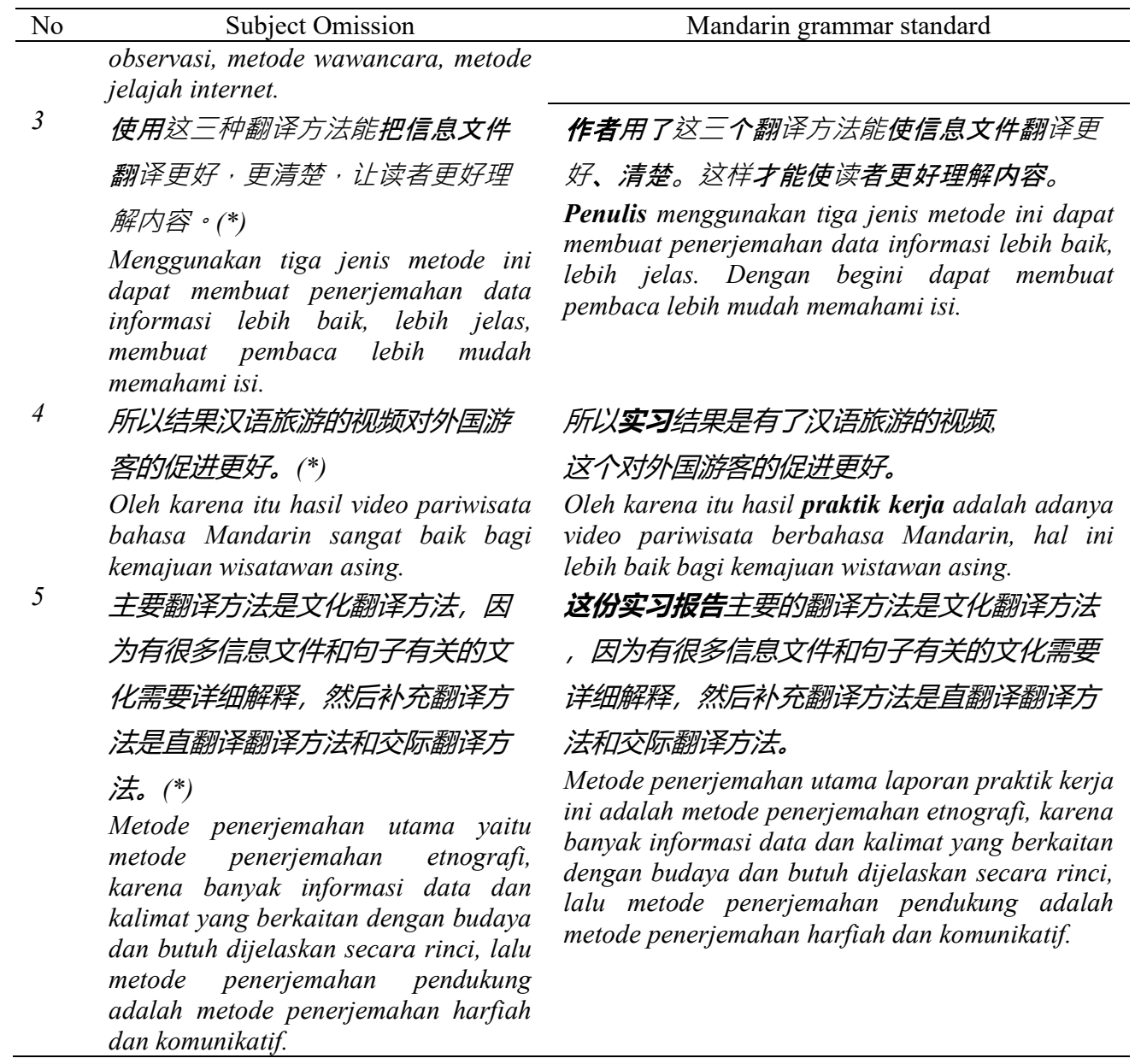

From the example about the errors in table 1, the first to the third sentences indicate that the sentence belongs to the category of language errors, namely the omission of subjects (zuòzhě). Then, the fourth sentence indicates the omission of words 实习 (shíxí) or practical word. While the next sentence shows that the omission of 这份实习报告（Zhè fè shíxí bàogào） or report on this practical work. The omission of the subject makes the sentence is not in accordance with the standard of Mandarin, so that the subject is added to clarify the meaning of the sentence, so as not to cause misunderstanding in the meaning.

\subsubsection{Auxiliary Omission}

Auxiliary or helping word or (Zhùcí) in Mandarin according to (Li Deyu, 2016: 38) is a word attached to a phrase or sentence to indicate various additional meanings. Auxiliary words in Mandarin cannot stand alone, and must be inserted behind the word to show different additional meanings. The following are some examples of errors in Auxiliary Omission found in the students' project report: 
Table 2: Auxiliary Omission

\begin{tabular}{|c|c|c|}
\hline No & Auxiliary Omission & Mandarin Grammar Standard \\
\hline \multirow[t]{5}{*}{1} & 实习的结论是这个活动提高作者在学术和 & 实习的结论是这个活动提高了作者在学术 \\
\hline & 专业方面领域的能力，提高在学术是在书 & 和专业方面领域的能力，提高在学术是在 \\
\hline & 写中文特别是旅游业的领域翻译的能力, & 书写中文特别是旅游业的领域翻译的能力 \\
\hline & 而在专业领域提高作者在工作。 & 而在专业领域提高作者在工作。 \\
\hline & $\begin{array}{l}\text { Kesimpulan dari praktik kerja adalah bahwa } \\
\text { kegiatan ini meningkatkan kemampuan } \\
\text { penulis dalam bidang akademik dan } \\
\text { profesional, meningkatkan kemampuan } \\
\text { menerjemahkan dalam bidang penulisan } \\
\text { bahasa Mandarin, khususnya pariwisata, dan } \\
\text { meningkatkan pekerjaan penulis di bidang } \\
\text { profesional. }\end{array}$ & $\begin{array}{l}\text { Kesimpulan dari praktik kerja adalah bahwa } \\
\text { kegiatan ini meningkatkan kemampuan } \\
\text { penulis dalam bidang akademik dan } \\
\text { profesional, meningkatkan kemampuan } \\
\text { menerjemahkan dalam bidang penulisan } \\
\text { bahasa Mandarin, khususnya pariwisata, dan } \\
\text { meningkatkan pekerjaan penulis di bidang } \\
\text { profesional. }\end{array}$ \\
\hline \multirow[t]{3}{*}{2} & 所以结果汉语旅游的视频对外国游客的促 & 所以实习结果是有了汉语旅游的视频, \\
\hline & 进更好。(*) & 这个对外国游客的促进更好。 \\
\hline & $\begin{array}{l}\text { Oleh karena itu hasil video pariwisata } \\
\text { bahasa Mandarin sangat baik bagi kemajuan } \\
\text { wisatawan asing. }\end{array}$ & $\begin{array}{l}\text { Oleh karena itu hasil praktik kerja ini adalah } \\
\text { adanya video pariwisata berbahasa } \\
\text { Mandarin, hal ini lebih baik bagi kemajuan } \\
\text { wistawan asing. }\end{array}$ \\
\hline \multirow[t]{5}{*}{3} & 主要翻译方法是文化翻译方法, 因为有很 & 这份实习报告主要的翻译方法是文化翻译 \\
\hline & 多信息文件和句子有关的文化需要详细解 & 方法, 因为有很多信息文件和句子有矨的 \\
\hline & 释, 然后补充翻译方法是直翻译翻译方法 & 文化需要详细解释，然后补充翻译方法是 \\
\hline & 和交际翻译方法。(*) & 直翻译翻译方法和交际翻译方法。 \\
\hline & $\begin{array}{l}\text { Metode penerjemahan utama yaitu } \\
\text { metode penerjemahan etnografi, karena } \\
\text { banyak informasi data dan kalimat yang } \\
\text { berkaitan dengan budaya dan butuh } \\
\text { dijelaskan secara rinci, lalu metode } \\
\text { penerjemahan pendukung adalah metode } \\
\text { penerjemahan harfiah dan komunikatif. }\end{array}$ & $\begin{array}{l}\text { Metode penerjemahan utama laporan } \\
\text { praktik kerja ini adalah metode } \\
\text { penerjemahan etnografi, karena banyak } \\
\text { informasi data dan kalimat yang berkaitan } \\
\text { dengan budaya dan butuh dijelaskan secara } \\
\text { rinci, lalu metode penerjemahan pendukung } \\
\text { adalah metode penerjemahan harfiah dan } \\
\text { komunikatif. }\end{array}$ \\
\hline \multirow[t]{4}{*}{4} & 作者在翻译旅游视频时用一种翻译方法是 & 作者在翻译旅游视频时使用了一个翻译方 \\
\hline & 交际翻译方法这样外国游客接受与理解翻 & 法是交际翻译方法这样外国游客能接受与 \\
\hline & 译的结果。 & 理解翻译的结果。 \\
\hline & $\begin{array}{c}\text { Penulis pada saat menerjemahkan } \\
\text { video wisata menggunakan satu jenis metode } \\
\text { penerjemahan yaitu metode komunikatif } \\
\text { dengan begini turis asing menerima dan } \\
\text { memahami hasil terjemahan. }\end{array}$ & $\begin{array}{c}\text { Penulis pada saat menerjemahkan } \\
\text { video wisata menggunakan satu jenis metode } \\
\text { penerjemahan yaitu metode komunikatif } \\
\text { dengan begini turis asing dapat menerima } \\
\text { dan memahami hasil terjemahan. }\end{array}$ \\
\hline \multirow[t]{2}{*}{5} & 翻译转单的过程有三个阶段。(*) & 作者在翻译转单的过程中有三个阶段。 \\
\hline & $\begin{array}{l}\text { Proses menerjemahkan brosur memiliki tiga } \\
\text { tahapan }\end{array}$ & $\begin{array}{l}\text { Penulis dalam proses penerjemahan memiliki } \\
\text { tiga tahapan }\end{array}$ \\
\hline
\end{tabular}


From the example of the error in table 2, it shows that the sentences are included in the category of language errors, namely Auxiliary Omission in the sentence. The Auxiliary in Mandarin are divided into two, 助词 or auxiliary words such as 、、地、了、呢、吧 and so on, whereas 助动词 or a verb for verbs includes 能会、想、之、应该、中 and so on. In the example of the first and second sentences there is a word omission 了 which should have existed and explained that the activity was completed. Whereas in the third sentence there is omission of the word "的" in front of "翻译方法" which stands as an attribute in a sentence or 定语, omission of "的" besides influencing the position of attributes in the sentence also makes the sentence less suitable for writing sentences or 书面语. In the fourth sentence there is an omission of auxiliary for the verb namely "能" (néng), in the sentence "能" serves to explain the word "接受" which stands as a verb in a sentence. The omission of the word "能" in the sentence causes the translation to be rough or not smooth. In the fourth sentence, there is the omission of the word "中" which functions to explain the activities carried out in the sentence. In Mandarin, there are pairs of words that must be used, one of which is "在 中", so the omission of the word "中" in the sentence violates the rules in Mandarin grammar.

\subsection{Adverb Omission}

Adverb or "状语" (Zhuàngyǔ) in Mandarin is placed in front of verb or verb to limit the verb or phrase formed by the verb. In this case, the researcher found an error in omitting adverbs in sentences, namely: 实习的结论是有美食的中文网站。However in the Mandarin grammar standard it should be 实习的实习是在西爪哇省旅游和文化部有了美食的中文网站。The researcher assumed that in the sentence, it must be added a place adverb namely 在西爪哇省旅游和文化部, which means the Culture and Tourism Office of West Java Province. If there is the place adverbs in the sentence, the sentence will become clearer if work practices are carried out in that place.

\subsection{Preposition Omission}

Preposition or 介词 (jiècí) according to (Li Deyu, 2016: 34) is a word used in front of nouns (group words) or pronouns to indicate time, place, direction, object, purpose, reason, basis, mode, passive, comparison, or exclusion of actions. Prepositions cannot be used alone, and must be used as information together with objects. The author found an error in removing prepositions in student sentences, namely: 实习的目的是翻译 senang loka 的印尼语的通知板翻译成汉语。(*). But the sentence that matches the Chinese grammar is 实习的目的是把Gembira Loka印尼语通知板翻译成汉语。The sentence contains an active sentence, although it doesn't change the meaning of the sentence, but the active sentence in Mandarin must use "把" as a preposition or conjunctions, so that the omission of conjunctions "把" is considered not to fulfill the rules of Mandarin grammar. 


\subsubsection{Addition}

Addition is the opposite Of Omission. Addition are marked by the presence of elements that should not appear in speech or sentences that are actuallu have been good and acceptable. Addition is included in the syntactic order error, which is the addition of errors that occur in phrases or sentences. The following are some of the errors the reseacher found in the the students' final projects:

\subsubsection{Verb Addition}

The verb or 动词 (dòngcí) according to (Li Deyu, 2016: 23) is a word that represents action, behavior, activity in mind, development, etc. Verbs in Mandarin especially verbs that state physiological conditions cannot be modified by adverb.

Table 3. Verb Addition

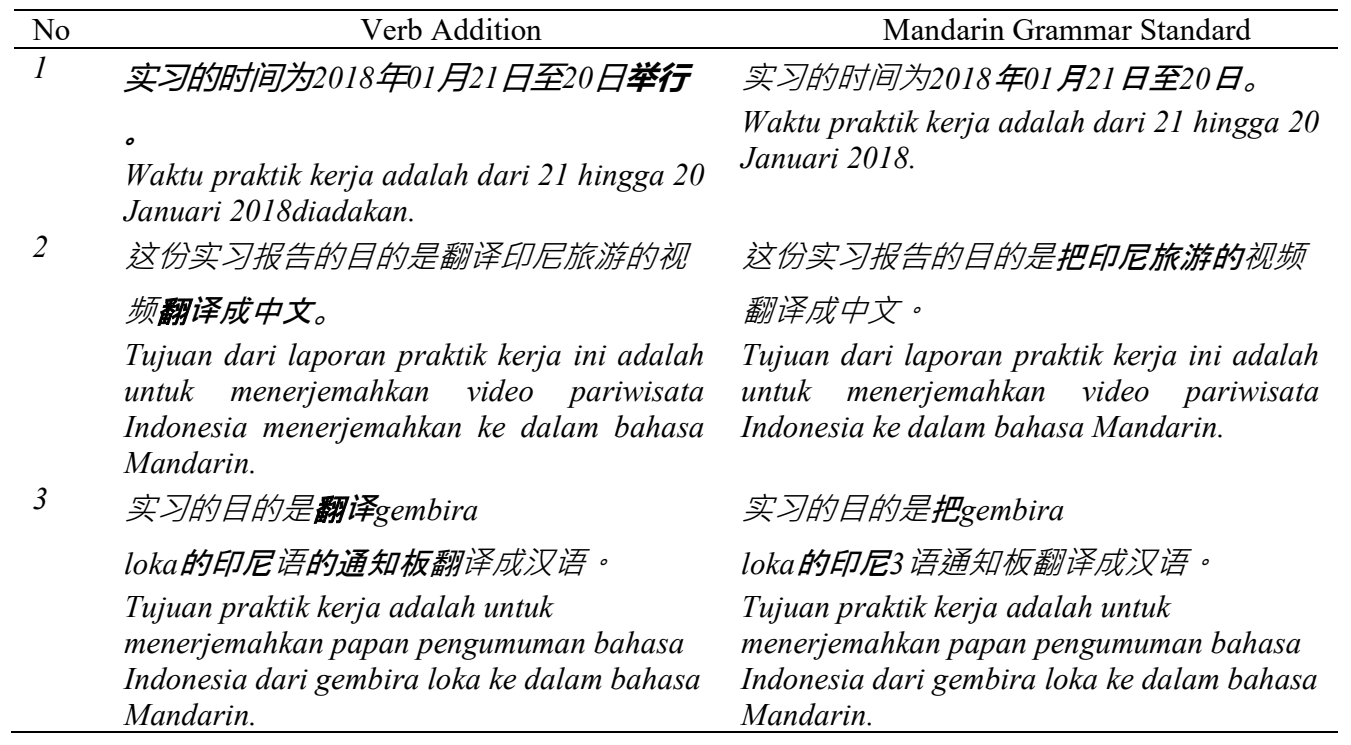

The results of a error analysis in Tiyao writing showed several errors in adding verbs. In Mandarin, ordinary verbs are placed after the subject, in the example of the first sentence, there is the word "diletakkan" which is placed at the end of the sentence, this is considered excessive because in the context of this sentence, it only describes the time of practical work, so it does not require the addition of verbs "举行 "in the sentence. The error in the second sentence is the addition of the verb "翻译" in the sentence. In this sentence, there are two words "翻译", but the Mandarin grammar is also incorrect, so it is necessary to reduce "翻译" to make the perfectly standardized sentence.

\subsubsection{Auxiliary Addition}

As explained, the word aids in Mandarin cannot stand alone, and must be inserted behind the word to show different additional meanings. The Addition errors which is found by the researcher are in the following example:

Table 4: Auxiliary Addition 


\begin{tabular}{|c|c|c|}
\hline No & Auxiliary Addition & Mandarin Grammar Standard \\
\hline 1 & 这份实习报告是翻译通知的。 & 这份实习报告是翻译通知。 \\
\hline \multirow{3}{*}{2} & $\begin{array}{l}\text { Laporan praktik kerja ini adalah } \\
\text { menerjemahkan pengumuman. }\end{array}$ & $\begin{array}{l}\text { Laporan praktik kerja ini adalah } \\
\text { menerjemahkan pengumuman. }\end{array}$ \\
\hline & 实习的目的是翻译gembira & 实习的目的是把gembira \\
\hline & $\begin{array}{l}\text { loka 的印尼语的通知板翻译成汉语。( } \\
\text { *) }\end{array}$ & $\begin{array}{l}\text { loka的印尼语通知板翻译成汉语。(*) } \\
\text { Tujuan praktik kerja adalah untuk }\end{array}$ \\
\hline \multirow{4}{*}{3} & $\begin{array}{l}\text { Tujuan praktik kerja adalah untuk } \\
\text { menerjemahkan papan pengumuman } \\
\text { bahasa Indonesia dari gembira loka ke } \\
\text { dalam bahasa Mandarin. }\end{array}$ & $\begin{array}{l}\text { menerjemahkan papan pengumuman bahasa } \\
\text { Indonesia dari gembira loka ke dalam bahasa } \\
\text { Mandarin. }\end{array}$ \\
\hline & 那个阶段是分析的，转移的，和重构 & \multirow{3}{*}{$\begin{array}{l}\text { 那个阶段是分析, 转移, 和重构的阶段。 } \\
\text { Tahap itu adalah tahap analisis, transfer, dan } \\
\text { refactoring. }\end{array}$} \\
\hline & 的阶段。 & \\
\hline & $\begin{array}{l}\text { Tahap itu adalah tahap analisis, transfer, } \\
\text { dan refactoring. }\end{array}$ & \\
\hline
\end{tabular}

These three sentences are examples of errors in adding particles, there is "的" in the sentence. Some of them are the addition of particles, for example, is the addition of the article at the end of the sentence in the following sentence: 这份实习报告是翻译通知的。With this addition at the end the sentence makes this sentence becomes the sentence that is suitable to be used in a conversation, besides that sentence "的" should be omitted at the end of the sentence. The same case happens in the sentence 那个阶段是分析的, 转移的, 和重构的。。The writer considers that "的" is simply written once in front of the words "分析" and "的" in front of the word "和" to be omitted. This is considered better and is not included in the inneffective of words in the sentence.

\subsubsection{Adjective Addition}

The third addition is the error of adding adjectives. Adjective or 形容词 according to (Li Deyu, 2016: 11) is a word that expresses a person's condition, shape, nature, or state of action, behavior, etc. Most adjectives can be modified with adverb degrees, but adjectives that indicate the state cannot be modified by adverb degrees. The researcher found the mistake of adding the adjective to the following sentence: 文化翻译方法对读者好接受和好理解。In this sentence there is the addition of the adjective "好" in front of the verb "理解", this is considered excessive, because in front of the verb "接受"There are already adjectives, so indirectly it also explains the verb behind it.

\subsubsection{Preposition Addition}

Errors in adding prepositions in students' final project reports are found in this sentence, 这些实习报告题为是： “Penerjemahan Brosur Benda Koleksi Museum Negeri Sonobudoyo Yogyakarta dari Bahasa Indonesia ke dalam Bahasa Mandarin”. In this case the author finds grammatical errors, namely the use of "为" which should not be used because there is already a "是" that functions as a predicate for the subject in that sentence.

\subsubsection{Misformation}


Formation errors or misformation are errors in the syntactic order which are characterized by errors in the use of the wrong morpheme or structure. Misformation are often made by students in writing Mandarin sentence formations, such as mis-selection of words in accordance with the context and sentence. In addition, word selection is very influential on the standard sentence. As we already know that in Mandarin there are words commonly used in 口头语 or official spoken and written languages or 书面语. Whereas Tiyao's writing is classified as academic / formal writing, so the author also focuses on the standard of Mandarin sentences. Therefore, in this study, the researchers focuse on the formation errors made by students in the selection of words for spoken sentences and formal written sentences. The following is the misformation found by the researchers in student's Tiyao:

Table 5: Misformation

\begin{tabular}{|c|c|c|}
\hline No & Misformation & Mandarin Grammar Standard \\
\hline \multirow[t]{4}{*}{1} & 这些实习报告题为是: “Penerjemahan & 这份实习报告题为是：“Penerjemahan \\
\hline & Brosur Benda Koleksi Museum Negeri & Brosur Benda Koleksi Museum Negeri \\
\hline & Sonobudoyo Yogyakarta dari Bahasa & Sonobudoyo Yogyakarta dari Bahasa \\
\hline & Indonesia ke dalam Bahasa Mandarin" & Indonesia ke dalam Bahasa Mandarin”。 \\
\hline \multirow[t]{3}{*}{2} & 实习举行从2018年1月22日到3月16日 & 实习时间为2018年1月22日到3月16日， \\
\hline & 在西爪哇省旅游和文化部。 & 实习是在西爪哇省旅游和文化部举行。 \\
\hline & $\begin{array}{l}\text { Praktik kerja diadakan dari } 22 \text { Januari } \\
\text { hingga } 16 \text { Maret } 2018 \text { di Kementerian } \\
\text { Pariwisata dan Kebudayaan Jawa Barat. }\end{array}$ & $\begin{array}{l}\text { Praktik kerja diadakan dari } 22 \text { Januari } \\
\text { hingga } 16 \text { Maret } 2018 \text { di Kementerian } \\
\text { Pariwisata dan Kebudayaan Jawa Barat. }\end{array}$ \\
\hline \multirow[t]{3}{*}{3} & 实习时间是从2018年01月22日到03月1 & 实习时间为2018年01月22日到03月16日 \\
\hline & 6日。 & 。 \\
\hline & $\begin{array}{l}\text { Waktu praktik kerja adalah dari } 22 \\
\text { Januari } 2018 \text { hingga } 16 \text { Maret. }\end{array}$ & $\begin{array}{l}\text { Waktu praktik kerja adalah dari } 22 \text { Januari } \\
2018 \text { hingga } 16 \text { Maret. }\end{array}$ \\
\hline \multirow[t]{2}{*}{4} & 作者用四种收集文件方法。 & 作者使用四个收集文件方法。 \\
\hline & $\begin{array}{l}\text { Penulis menggunakan empat } \\
\text { metodepengumpulan data. }\end{array}$ & $\begin{array}{l}\text { Penulis menggunakan empat metode } \\
\text { pengumpulan file. }\end{array}$ \\
\hline \multirow[t]{4}{*}{5} & 作者用四种收集资料的方法即：观察 & 作者使用四个收集资料的方法即：观察 \\
\hline & 方法, 图书馆研究方法, 采访方法, & 方法, 图书馆研究方法, 采访方法, 和 \\
\hline & 和汶览互联网。 & 汶览互联网。 \\
\hline & $\begin{array}{l}\text { Penulis menggunakan empat metode } \\
\text { pengumpulan data: metode observasi, } \\
\text { metode penelitian perpustakaan, metode } \\
\text { wawancara, dan jelajah internet. }\end{array}$ & $\begin{array}{l}\text { Penulis menggunakan empat metode } \\
\text { pengumpulan data: metode observasi, } \\
\text { metode penelitian perpustakaan, metode } \\
\text { wawancara, dan jelajah internet. }\end{array}$ \\
\hline \multirow[t]{3}{*}{6} & 翻译描述的信息是作者用两种翻译方 & 翻译描述的信息是作者使用两个翻译方 \\
\hline & 法。(*) & 法。 \\
\hline & $\begin{array}{l}\text { Informasi yang dijelaskan dalam } \\
\text { terjemahan adalah dua metode } \\
\text { terjemahan penulis. }\end{array}$ & $\begin{array}{l}\text { Informasi yang dijelaskan dalam } \\
\text { terjemahan adalah dua metode terjemahan } \\
\text { penulis. }\end{array}$ \\
\hline \multirow[t]{3}{*}{7} & 直译翻译方法为第一阶段翻译信息文 & 直译翻译方法作为第一阶段翻译信息文 \\
\hline & 件, 交际翻译方法为重组翻译的句子 & 件, 交际翻译方法作为补充翻译方法。 \\
\hline & 结构。使用这三种翻译方法能把信息 & 使用这两个翻译方法能把信息文件翻译 \\
\hline
\end{tabular}




\begin{tabular}{|c|c|}
\hline 文件翻译更好, 更清楚, 让读者更好 & 更好, 更清楚, 让读者更好理解内容。 \\
\hline 理解内容。 & Metode penerjemahan harfiah sebagai \\
\hline $\begin{array}{l}\text { Metode penerjemahan harfiah sebagai } \\
\text { tahap pertama penerjemahkan } \\
\text { data,metode komunikatif sebagai metode } \\
\text { pendukung penerjemahan struktur } \\
\text { kalimat. Menggunakan ketiga metode } \\
\text { dapat membuat hasil terjemahan lebih } \\
\text { baik, lebih jelas, membuat pembaca lebih } \\
\text { mudah memahasi isi. }\end{array}$ & $\begin{array}{l}\text { tahap pertama penerjemahkan data,metode } \\
\text { komunikatif sebagai metode pendukung } \\
\text { penerjemahan struktur kalimat. } \\
\text { Menggunakan ketiga metode dapat } \\
\text { membuat hasil terjemahan lebih baik, lebih } \\
\text { jelas, membuat pembaca lebih mudah } \\
\text { memahasi isi. }\end{array}$ \\
\hline
\end{tabular}

Based on the table of misformation above shows that when students prepare the final project report, there are still errors in compiling Mandarin sentences, especially in choosing the right words, especially words that are more appropriate to be used in formal written language. In the first example, the student uses the word "些" to explain the practical work report or "实习报告", this clearly violates the rules of Mandarin grammar, because "些" is only used to explain things or something a few amount, while the practical work report consists of several chapters, so you have to use a number or 量词 "份" auxiliary. In the second sentence, students use the word "举行从" while behind it, it is followed by a description of time namely"2018 年 1 月 22 日到 3 月 16 日". The researchers assume that there is a direct transfer of language from Indonesian to Mandarin, so that in writing the sentence, the student is encouraged to the word "held on" so that the word "举行从" is used, but to make the sentence into a good standardized language. Then, the word "举行从" must be replaced with the word "时间为" , thus it will relate to the word behind it. The same thing is also found in the third sentence, to explain a statement of time you should use the word "是从" to "为". In the fourth, fifth and sixth sentence there are the same form of errors, namely the misuse of the word "用", basically the use of this word is not grammatically incorrect, but the researchers choose to classify them as word selection misformations due to its level of formality, so the researchers prefer to use the word "使用". In the seventh sentence, the researchers discover errors in the use of the words "sebagai" or it is written as "为", in addition to explaining that “communicative methods are supporting methods" should use the word "补充翻译方法" instead of using "重组翻译的句子结构 ", so the correct sentence is" 交际翻译方法作为补充翻译方法

\subsubsection{Misordering}

Misodering is an error in the syntactic order which is characterized by incorrect placement of a morpheme or morpheme group in a sentence. The complete sentence structure in Mandarin consists of: 主语 Subject + 谓语 Predicate + 宾语 Object + 定语 Attribute + 状语 Adverbial + 补语 Complement. Whereas the Adverb of the time or Adverb of the place in Mandarin is located very differently from the Indonesian In Mandarin, the adverb of time or 
information about the place can be placed in front of or behind the subject. Following are the errors in the final project report writing of the students:

Table 6. Misordering

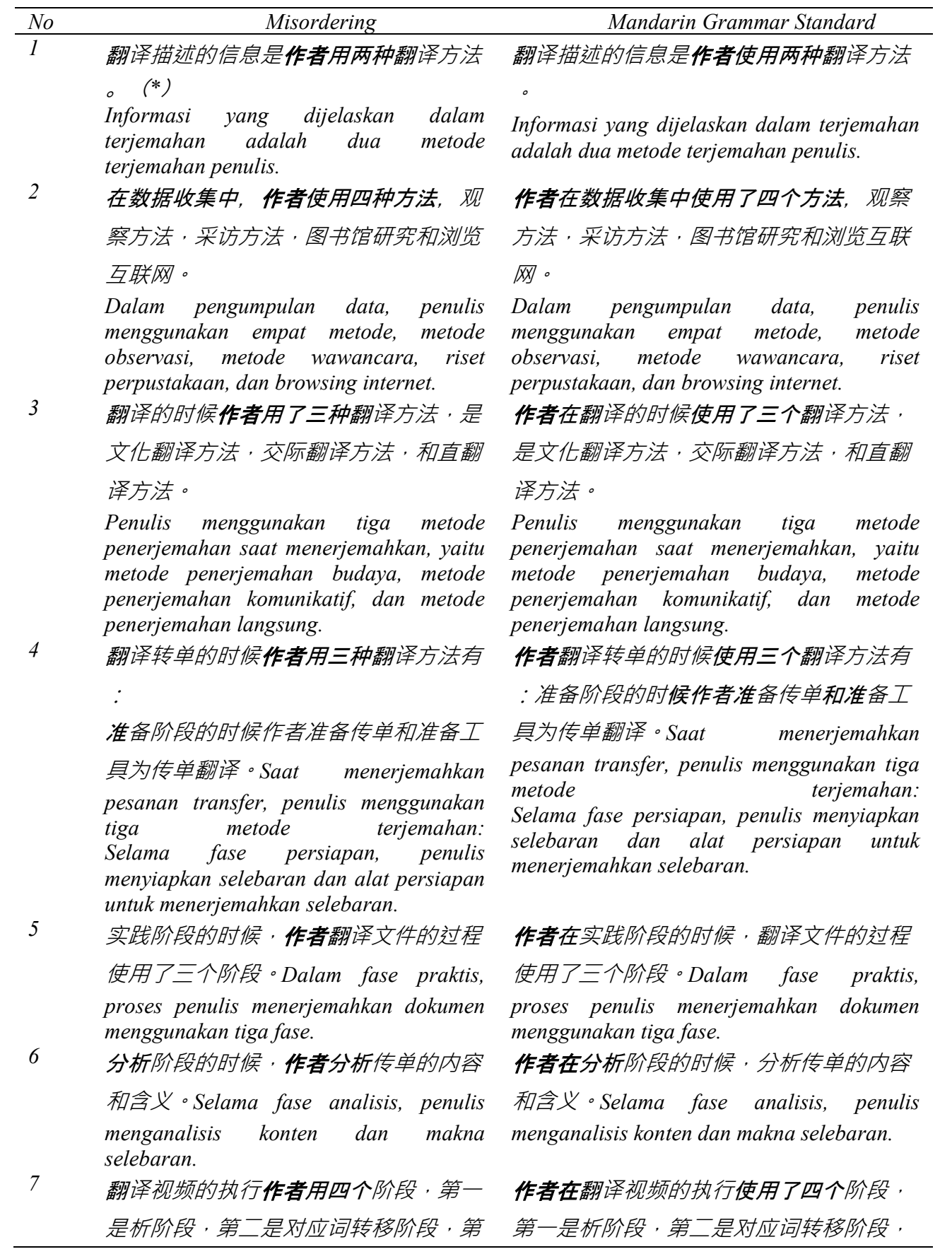




\begin{tabular}{ll}
\hline 三是调整阶段和第四是评估与修订阶段 & 第三是调整阶段和第四是评估与修订阶段 \\
。Penulis video yang diterjemahkan & 。Penulis video yang diterjemahkan \\
menggunakan empat tahap, yang pertama & menggunakan empat tahap, yang pertama \\
adalah fase analisis, yang kedua adalah & adalah fase analisis, yang kedua adalah fase \\
fase transfer kata yang sesuai, yang ketiga & fransfer kata yang sesuai, yang ketiga adalah \\
adalah fase penyesuaian dan yang & fase penyesuaian dan yang keempat adalah \\
keempat adalah fase evaluasi dan revisi. & fase evaluasi dan revisi. \\
实习的目的是把西爪哇省旅游和文化部 & 实习的目的是把西爪哇省旅游和文化部的 \\
的网站美食从印尼语翻译成汉语。Tuju & 美食网站从印尼语翻译成汉语。Tujuan \\
an magang adalah untuk menerjemahkan & magang adalah untuk menerjemahkan \\
masakan dari Kementerian Pariwisata & masakan dari Kementerian Pariwisata dan \\
dan Kebudayaan Provinsi Jawa Barat & Kebudayaan Provinsi Jawa Barat dari \\
dari Indonesia ke Cina. & Indonesia ke Cina. \\
\hline
\end{tabular}

In this study, it is found a subject matter error. In Mandarin, subject can be placed before or after the time adverbial, but should not be placed behind the verb. The above table of Misordering shows that standard $\mathrm{S}+\mathrm{P}+\mathrm{O}+\mathrm{K}$ often are misordered. These kind of errors are still found in the students final project reports, thus affecting the meaning and validity of Mandarin grammar. The first to the seventh sentences have the same form of error, that is the misorder of subjects in sentences, namely "作者". While in the eighth sentence, there are errors in ordering nouns and adjectives. In Mandarin, adjectives are always put in front of nouns, so in the example the eighth sentence has misorder of "网站" and "美食" .

\section{Conclusion}

Based on the results of the research which is conducted using the Students' Final Project of the Mandarin Associate Degree Program at Universitas Jenderal Soedirman Purwokerto, conclusion can be drawn.Based on the Tiyao of the Students' Final Project of the Mandarin Associate Degree Program at Universitas Jenderal Soedirman Purwokerto, it is found several forms of errors, namely: Omission, aaddition, misformation, and misordering. The first error is Omission, in this case, the researchers found several types of omission errors; subect omission, auxiliary omission, and adverbial omission. The second form of error is addition, in this case also found several types of errors, namely verb addition, auxiliary addition, adjectives addition, and preposition addition. Furthermore, Formation errors are found in choosing the right words to be used in formal writings such as tiyao. Then, the last form of error is Misordering, the most dominant error made by students is the standard sentence order of $\mathrm{S}+\mathrm{P}+\mathrm{O}+\mathrm{K}$, especially the placement of inappropriate subjects. Factors causing errors in Tiyao's writing are the lack of students' understanding and mastery which causes interference; the influence of the environment where the students rarely use Mandarin in daily conversations; the influence of mother tongue; the lack of students' practices in writing Mandarin sentences using correct grammar. By conducting the research on errors in tiyao writing as the students' final project reports, it is expected to be the input and references for Mandarin language instructors or lecturers especially in Mandarin Associate Degree Program in UNSOED, so that the students can profitably minimize errors and the students can be well trained to write tiyaowith correct procedure in standardized Mandarin. 


\section{References}

[1] Cai'en, Liu. 词语用法详解. Beijing: 北京语言文化大学出版社. .(2001)

[2] Delu, Li.汉语语法教学. Beijing: 北京语言大学出版社. (2016). pp. 11-38

[3] Jianqin, Wang. 第二语言习得研究. Beijing: 商务印书馆出版社. (2012)

[4] Mansoer, Pateda. Analisis Kesalahan. Flores. NTT: Nusa Indah. (1989)

[5] Parera, Jos Daniel. Dasar-Dasar Analisis Sintaksis. Jakarta: Erlangga press. (2009)

[6] Rusmadji, Oscar. Aspek-aspek Sintaksis. Malang: IKIP Malang. (1993)

[7] Sukardi. Metodologi Penelitian Pendidikan. Jakarta: Bumi Aksara. (2003)

[8] Tarigan \& Guntur, Henry. Prinsip-prinsip Dasar Sintaksis. Bandung: Angkasa. (1986).

[9] Tarigan \& Guntur, Henry. Pengajaran Analisis Kesalahan Berbahasa. Bandung: Angkasa Bandung. (1988).

[10] Xiaochuan, Peng, dkk. 对外汉语教学语法释疑201 例. Beijing: 商务书馆. (2013).

[11] Xun, Liu. 对外汉语教育学引论. Beijing: 北京语言大学出版社. (2010)

[12] Shuxiang, Lu. 现代汉语八百词. Beijing: 商务印书馆. (2016) 